Sosyoloji Derneği, Türkiye

Sosyoloji Araştırmaları Dergisi

Cilt: 17 Sayı: 2 - Güz 2014

Sociological Association, Turkey

Journal of Sociological Research

Vol.:17 Nr.: 2 - Fall 2014

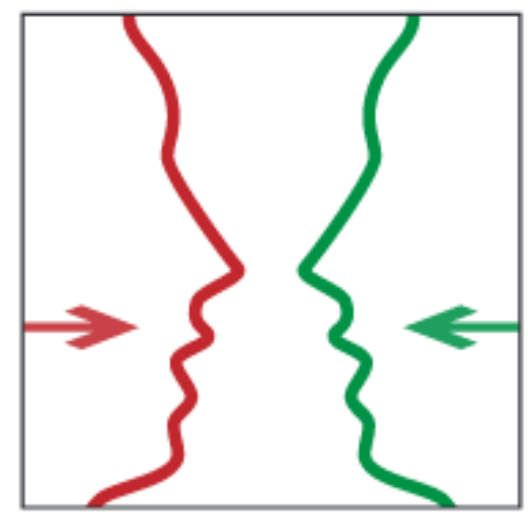

What Affects the Quality of Work Life Most?: Turkey Example

Selda Taşdemir AFŞAR 


\title{
What Affects the Quality of Work Life Most?: Turkey Example
}

\section{Selda Taşdemir AFŞAR*}

\begin{abstract}
This study aims to examine whether there is a significant correlation between the quality of work life and academic title, wages, total number of years in the organisation, total number of years at position, type of employment, work arrangement type (full-time, part-time, etc.), overtime, perceptions about protective nature of the organisation as well as such demographic characteristics as age, gender and marital status, and also looks at the impact of these variables on the quality of work life. The sample was composed of 570 academics from 4 universities in Ankara. Correlation analysis revealed a positive and significant correlation between the quality of work life and academic title, total number of years in the organisation, total number of years at position, wages, age and gender whereas it showed a significant negative correlation between the quality of work life and type of employment, marital status and protective nature of the organisation.
\end{abstract}

Key Words: Quality of Work Life, Working Conditions, Organisational Protectiveness, Demographical Characteristics

* Dr. Hacettepe Üniversitesi, Edebiyat Fakültesi, Sosyoloji Bölümü. 


\section{Çalışma Yaşam Kalitesini En Çok Ne Etkiler?: Türkiye Örneği}

$\ddot{\mathbf{O} z}$

Bu çalışma, çalışma yaşam kalitesinin akademik unvan, ücret, örgütteki toplam çalışma yılı, pozisyondaki toplam çalışma yılı, istihdam biçimi, çalışma şekli (full-time, part-time, etc.) ve fazla mesai, örgütün koruyucu olup olmadığına yönelik algı ile yaş, cinsiyet ve medeni durum gibi demografik özellikler ile arasında anlamlı bir ilişki olup olmadığını ve tüm bu değişkenlerin çalışma yaşam kalitesi üzerindeki etkisini incelemektedir. Çalışmanın örneklemini, Ankara'daki 4 üniversite çalışan 570 akademisyen oluşturmaktadır. Yapılan korelasyon analizinde çalışma yaşam kalitesi ile akademik unvan, örgütteki çalışma süresi, pozisyondaki çalışma süresi, ücret, yaş ve cinsiyet arasında pozitif ve anlamlı bir ilişki; çalışma yaşam kalitesi ile istihdam biçimi, medeni durum ve örgütün koruyucu olup olmadığına yönelik alg1 arasında negatif ve anlamlı bir ilişki bulunmuştur.

Anahtar Kelimeler: Çalışma Yaşam Kalitesi, Çalışma Koşulları, Örgütsel Koruyuculuk, Demoğrafik Özellikler 


\section{Introduction}

Although the first scientific use of the term of quality of work life (QWL) roots back to 1970s, activities for improving working conditions to improve workers' productivity and organisation's profitability were started in the first quarter of 1900s. The fuse of this application was lit in 1930s through the Hawthorne experimental kit by Elton Mayo and his friends (Greenberg and Baron 1993). The idea of the Quality of Work Life took root inside the special context of working conditions of industrialised societies towards the end of 1950s, and emphasised humanisation of the aspects of work and improvement of working conditions of the employees by focusing on the quality of the relationship between worker and working environment at the beginning of 1960s. The notion of the improvement of working conditions was triggered by such problems as "objectivisation of labour", "deskilling of workers", "inhuman cases - dehumanisation" and "alienation" caused by a type of production under the impact of Taylorist and Fordist arguments (Hannif et al. 2008; Davis and Cherns 1975; Martel and Dupuis 2006; Rose et al. 2006). Rationalism and economic human approach accompanying Taylorism ensured industrial development particularly in Europe and North America, yet brought some unrest with it. Besides several problems such as job dissatisfaction, job alienation, bad working environment and conditions or wage inequality caused by the struggle between employer and employee, global crises as well as political, social and economic changes also made it essential for enterprises to try new ways. The only subject of this change is "human". Within this context, "how to make the work life and worker more qualified" has become an important problem exclusively for developed countries. 
The first generic, systematic and applied approach on the quality of work life was of Eric Trist, Fred Emery, A. Rice, Hans von Beinum and their colleagues in 1950s in Tavistock Human Relations Institute in London. The Institute developed a system, called "socio-technical system" that integrated the work structure, the employees and technology, and also revealed the relationship among them and all other factors within themselves as well as administrative functions. In the socio-technical system, human is a resource that needs to be improved. An employee can use his own initiative, bring suggestions or participate actively. There is collaboration between manager and employees. This system foresees productivity growth through improvement of the quality of work life, and equal sharing of earnings among management, employees and consumers (Jenkins 1981; Can 1991).

The Quality of Work Life was put forward as a discipline in 1972 in the International Conference on the "Democratization of Work" held at Colombia University's Arden House. Thanks to this conference, the concept of the quality of work life was introduced, and the International Council for the Quality of Working Life was established to promote research and practice in relation to this concept. This Council defined the quality of work life as "a process that appears in all levels of an organisation as well as in every activity / event with a greater organisational effectiveness through human dignity and development" (Martel and Dupuis 2006). In 1980, a weekend meeting was organised in Canada to discuss recommendations of the Council, and the first international conference was organised in August in Toronto on the "Quality of Work Life and 1980s" (Yousuf 1995). These conferences led to a restructuring and development of a new business concept that enabled participation of individuals and groups. In parallel, expectations of the employees have started to vary. This variety, along with the development of individual and institutional factors having an influence on the quality of work in parallel with the institutional goals and objectives, implies consideration of the expectations and needs of the workers. The concept of the quality of work life, being one of the prerequisites 
for institutional productivity, has become functional in line with this restructuring (DuBrin 1988).

The studies conducted in the 1970's embraced an understanding more focused on the profitability through productivity growth than the human aspect on the advantage of workers for the quality of work life whereas the studies in the 1980's foregrounded workers' satisfaction and happiness about his work and workplace. Thus, the idea of quality in work life has gradually started to take its current shape. Now, organisations have started to target provision of workers with necessary conditions to work in a more productive manner in the process of realising their basic goals such as profitability, growth and continuity (Cobb 2000). Within this framework, it may be said that the quality of work life has two goals. The first goal is to increase productivity, and the second is to increase satisfaction of employees (Lawler 1982; Kotze 2005; Bhola 2006). So, the quality of work life is a response both to organisational needs and to workers' developmental needs, a practice to improve working conditions, and a series of measures.

Quality of work life is a very broad concept, therefore, there is no one single, clear definition of the Quality of work Life. QWL is defined as "the interaction between work environment and personal needs (personal needs are satisfied when rewards from the organisation, such as compensation, promotion, recognition and development meet their expectations)" (Hackman and Oldham 1980); "the quality of the relationship between employees and the total working environment, with human dimensions added to the usual technical and economic considerations" (Davis 1983); "a way of thinking about people, work and organisations" (Nadler and Lawler 1983); "quality of working life was associated with satisfaction with wages, hours and working conditions, describing the "basic elements of a good quality of work life" as; safe work environment, equitable wages, equal employment 
opportunities and opportunities for advancement (Mirvis and Lawler 1984); "the workplace strategies, operations and environment that promote and maintain employee satisfaction aimed at improving working conditions for employees and organisational effectiveness" (Lau and Bruce 1998); "a generic concept that covers a person's feelings about every dimension of work, and a way of thinking about people, work and organization that involves a concern for employee well-being and organizational effectiveness" (Yousuf 1996; Cummings and Worley 1997); “employee satisfaction with a variety of needs through resources, activities, and outcomes stemming from participation in the workplace" (Sirgy et al. 2001); "the favourable working environment that supports and promotes satisfaction by providing employees with rewards, job security and career growth opportunities" (Lau et al. 2001).

Directly the definitions indicate that QWL is a dynamic multidimensional construct that includes such concepts as job security, reward systems, training and career advancements opportunities, and participation in decision making (Saraji and Dargahi, 2006). Walton (1975) proposed eight major conceptual categories relating to QWL as (1) adequate and fair compensation, (2) safe and healthy working conditions, (3) immediate opportunity to use and develop human capacities, (4) opportunity for continued growth and security, (5) social integration in the work organization, (6) constitutionalism in the work organization, (7) work and total life space and (8) social relevance of work life. Additionally, many studies conducted in this area (Glasier 1976; Lau and Bruce 1998; Hackman and Oldham 1975; Wurf 1982; Chisholm 1983; Dereli 1991; Shamir and Salomon 1985; Rose et al. 2006; Sirgy et al. 2001; Kohl ve Shooler 1982) reveal that the quality of work life includes many aspects such as employment conditions, employment security, income adequacy, profit sharing, equity and other rewards, employee autonomy, employee commitment, social interaction, self- esteem, selfexpression, democracy, employee satisfaction, employee involvement, advancement, relations with supervisors and peers and job enrichment. 
As can be understood from above definitions, the quality of work life is a multidimensional structure. Many studies (Groot and Brink 2000; Igbaria et al. 1994; Lewis et al. 2001; Sirgy et al. 2001; Beh 2006; Rose et al. 2006; Judge and Bretz 1994; Rethinam and Ismail 2008) have resulted that the quality of work like differ in line with several variables, and it is influenced by several variables at various levels. In the light of these, this study examines whether the quality of work life differs by the working conditions of employees, the perception about protective nature of organisation and demographics, and it explores which variables influences the quality of work life most. ${ }^{1}$

\section{Indicators of the Quality of Work Life}

\subsection{QWL and Salary}

Salary satisfaction of employees not only influences both the quality of work life and several important organisational outcomes, but it is also considered as one of the crucial factors to measure and evaluate the quality of work life (Locke 1976:7-8). Satisfactory, fair and equal salary is one of the milestones of the quality of work life, which means that if the employee is satisfied with his salary in return for his services his quality of work life is high as well (Groot and Brink 2000; Igbaria et al. 1994; Lewis et al. 2001; Sirgy et al. 2001; Bolhari et al. 2011). If the organisation does not ensure a satisfactory level of payment, the employee cannot commit himself to his job since he will be thinking of his struggle for survival. Based on this discussion, we proposed the following:

Hypothesis 1: There is a significant positive correlation between salary and the quality of work life.

\subsection{QWL and Academic Title/Qualification}

\footnotetext{
${ }^{1}$ The study includes academic title, salary, total number of years in the organisation, staffing pattern, total number of years at the position under the general title of work style and overtime working conditions.
} 
Employees do generally fight for success, attention and personal development in their jobs, and wish to improve their job performance. The career level of an employee points to his professional success and prestige hierarchy at work. If an employee's career provides him with higher prestige, income and power compared to the other posts, it satisfies him more (Rose et al. 2006: 62). The quality of work life is also surrounded by career development practices, which means that career aspect (e.g. career success, career satisfaction and career balance) does have a positive impact on the quality of work life (Beh 2006; Rose et al. 2006). Rose et al. (2006) considers career as the most important indicator of the quality of work life. A study on the quality of work life of academicians (Winter et al. 2000) has resulted in a positive correlation between academic titles of the academicians and the quality of work life. Since the sample of this study is also comprised of academicians, the correlation between the academic title and the quality of work life has hypothesised as follows:

\section{Hypothesis 2: There is a significant positive correlation between academic title and the quality of work life.}

\subsection{QWL and Duration of Work}

According to Rose et al. (2006), there is a positive relationship between the total duration of work, total duration of work with the current employer, total duration of work at current position, total number of working years, and the quality of work life. In all cases, the quality of work life improves as the duration of work increases (Judge and Bretz 1994; Rose et al. 2006; Bolhari et al. 2011). On the other hand, studies have revealed that the quality of work life of an employee working in the same organisation for a long period of time, and that is why he does not quit working for that organisation (Gürsel et al. 2003:151). These relationships are embodied in the following hypotheses.

Hypothesis 3: There is a significant positive correlation between the total duration of work in the organisation and the quality of work life. 
Hypothesis 4: There is a significant positive correlation between the total duration of work at the current position and the quality of work life.

\subsection{QWL, Form of Employment and Work Arrangement}

Both reports of the Organization of Economic Cooperation and Development (OECD) (Rethinam and Ismail 2008) and several studies conducted (Winter at al. 2000; Igbaria et al. 1994) state that payroll or contracted employment, in other words job security, is the most debated situation in the business world, that job security is at the core of the quality of work life, and that the existence of job security improves the quality of work life. This is because it is difficult for employees of the sectors with faster labour force cycle to integrate with their job. No employee having a fear of losing his job can work efficiently. Any employee who is confident about his future will have an improved productivity owing to the quality of work life (Y1lmaz 1990). A research study conducted with Brisa, one of the leading tyre companies worldwide, has concluded that employees are paid high salaries, almost all employees have their own vehicles and almost $80 \%$ their own houses, yet the most important factor for the employees in work life is job security rather than high salaries. According to Necef (Yıldırım 2000), the findings of this study indicate that $90 \%$ of the employees in Brisa consider job security as the factor with highest priority. This leads us to our fifth hypothesis:

Hypothesis 5: There is a significant positive correlation between the form of employment and the quality of work life.

On the other hand, another factor that has an influence on the quality of work life is employees' work arrangement (Sirgy et al. 2008; Ssesanga and Garret 2005). Work arrangements include full-time, part-time, hour-based, etc. (Kalleberg 2000:241). The quality of work life and forms of employment are hypostasised as follows: 
Hypothesis 6: There is a significant positive correlation between work arrangement and the quality of work life.

\subsection{QWL and Overtime}

Several studies indicate that the quality of work life differs by work hours. Work hours are considered in terms of standard work hours, workload and overtime. Work hours also have an important place in studies conducted on the quality of life as well as on the quality of work life in that it helps employees to establish a balance between their job and their families, and removes any possibility of conflict between these two areas. When working hours are short or employees do not have to work overtime, they can allocate more time to their private lives, their families and friends. Since this will increase satisfaction and content about other areas of life as well as work life, it is generally considered as a state improving the quality of work life as well as the quality of life accordingly (Arnold and Feldman 1986). A study conducted by Winter et al. (2000) about the quality of work life of Australian academicians has revealed that extra working hours particularly mean extra workload, and consequently have a negative impact on the quality of work life of the academicians. Similarly, another study conducted by Baba and Jamal (1991) in the biggest hospital of Montreal region of Canada with the participation of 1,120 nurses has resulted in that standard and definite working hours with no overtime have a positive impact on the quality of work life. The study conducted by Sirgy et al. (2001) and Sirgy et al. (2008) has concluded that extra workload and overtime create emotional distress and thus decrease the quality of work life. The relationship between quality of work life and work hours leads to our hypothesis:

Hypothesis 7: There is a significant positive correlation between overtime and the quality of work life. 


\subsection{QWL and Perceived Organisational Protectiveness}

State of perception towards organisational protectiveness has been developed from the concept and idea of organisational support brought forward by studies of Eisenberger et al. (1986). Organisational support may be defined as concerning the extent "to which the organisation values their contributions and cares about their well-being" (Eisenberger et al. 1986:501), "to which the organisation is aware of its employees' contribution and cares about welfare of its personnel" (Naumann et. al. 1995:89), and "to which the employees of the organisation feel themselves safe and protected by the organisation" (Özdevecioğlu 2003:116). For the purposes of this study, the concept of organisational protectiveness is defined as a state in which the organisation shows a protective and safeguarding attitude towards its employees in every aspect (e.g. personal, professional) including organisational support. The perception about organisational protectiveness is a personal issue varying from person to person. This study measures the employees' perception about organisational protectiveness with the following question: "Do you think the university you are working for treats you in a protective, safeguarding and embracing manner?" Whether the quality of work life differ in terms of employees' perception about organisational protectiveness is hypothesised as follows:

\section{Hypothesis 8: There is a significant positive correlation between the perception of} organisational protectiveness and the quality of work life.

\subsection{QWL and Demographics}

There are several studies dealing with the relationship between the quality of work life and age, gender and marital status (Igbaria et al. 1994; Ssesanga and Garrett, 2005; Rose et al. 2006; Koonmee and Virakul 2007; Bolhari et al. 2011; Rose et al. 2006). The following hypotheses have been tested in the light of these studies: 
Hypothesis 9a: There is a significant positive correlation between age and the quality of work life.

Hypothesis 9b: There is a significant positive correlation between gender and the quality of work life.

Hypothesis 9c: There is a significant positive correlation between marital status and the quality of work life.

In addition to the above hypotheses, this study will seek to answer the following question:

- Which of the following does have more impact on the quality of work life: work conditions, perception about organisational protectiveness or demographics?

\section{Method}

\subsection{Sampling}

Sample of this study is consisted of faculty members working for the faculties of Science, Literature, Education, Engineering and Economics and Administrative Sciences of four universities in Ankara, Turkey, namely (Hacettepe University, Gazi University, Bilkent University and Başkent University). It was planned to collect data via a web-based survey, but it was only possible to collect data using the web-based survey at one university. In the other three universities, the questionnaire and the QWL scale were delivered to the faculty members and collected by the researcher. A total of 570 completed questionnaires were returned.

\subsection{Instruments}

QWL Scale: The Quality of Work Life Scale (QWLS) developed by Sirgy et al. (2001) and adapted to Turkish culture by Tasdemir-Afsar (2011) was used to measure the quality of work life. The QWLS was conceptualised as satisfaction of seven needs namely need for health and safety, economic and domestic needs, social needs, need for recognition/respectability, need for self-realisation, need for knowledge and aesthetic needs. The scale includes 16 items. 
The respondents were asked to respond to each item by checking a 7-point scale ranging from "strongly disagree" (value of 1) to "strongly agree" (value of 7). Cronbach Alpha reliability coefficient of the Quality of Work Life Scale (QWLS) developed by Sirgy et al. (2001) is reported as 0.78. In this study, Cronbach Alpha reliability coefficient of the quality of work life scale is calculated as 0.88 .

Besides, a questionnaire of 14 questions was prepared to collect data on the demographics of the participants, their working conditions and their perception about organisational protectiveness.

\subsection{Data Analysis}

The collected data was analysed using SPSS (Statistical Packet for Social Sciences 16.0), and interpreted by the researcher. Analysis of the data collected as a result of the questionnaire and QWLS took into consideration demographics and "percentage" and "frequency" values for the working conditions data. A "correlation" test was conducted to see whether there is a relationship between the quality of work life and the working conditions. A "Hierarchical Multiple Regression Analysis" to see the impact of relevant variables on the quality of work life and which variable has the most impact.

\section{Results}

\subsection{Respondent Profile}

The majority of the participants (19.6\%) are in the 26-30 age group, $60.8 \%$ are married, and $55.1 \%$ are male. $33.6 \%$ of the participants are working as research assistants, $28.3 \%$ are working at the current university for 2 to 5 years, and $47.4 \%$ are working at the current position for 2 to 5 years. $36.8 \%$ of the participants receive a salary between 1,501 TL to 2,000 TL, 55.7\% 
are subject to a fixed term contract, $94.4 \%$ are employed full time, and $27.8 \%$ do overtime between six to ten hours every week. The profile of the sample is summarised in Table 1.

Table 1 Respondent Profile ${ }^{2}$

\begin{tabular}{|c|c|c|c|c|c|}
\hline \multirow[t]{2}{*}{ Variables } & \multicolumn{3}{|r|}{ Variables } & \multirow[b]{2}{*}{ Frequency } & \multirow[b]{2}{*}{$\%$} \\
\hline & Frequency & $\%$ & & & \\
\hline Sex & & & Duration at Position & & \\
\hline Female & 259 & 44.9 & 1 year or less & 91 & 15.9 \\
\hline Male & 311 & 55.1 & $2-5$ years & 276 & 47.4 \\
\hline Total & 570 & 100.0 & $6-10$ years & 122 & 22.0 \\
\hline Age & & & $11-15$ years & 38 & 6.7 \\
\hline 25 or under & 43 & 8.1 & $16-20$ years & 21 & 3.9 \\
\hline $26-30$ & 116 & 19.6 & 21 years or over & 22 & 4.1 \\
\hline $31-35$ & 97 & 17.1 & Total & 570 & 100.0 \\
\hline $36-40$ & 78 & 13.6 & Salary & & \\
\hline $41-45$ & 69 & 11.9 & 1,500 TL or under & 66 & 13.9 \\
\hline $46-50$ & 62 & 10.9 & $1,501-2,000 \mathrm{TL}$ & 241 & 36.8 \\
\hline 51 or over & 105 & 18.8 & $2,001-2,500 \mathrm{TL}$ & 67 & 11.7 \\
\hline Total & 570 & 100.0 & $2,501-3,000 \mathrm{TL}$ & 45 & 8.4 \\
\hline Marital Status & & & $3,001 \mathrm{TL}$ or over & 151 & 29.2 \\
\hline Married & 344 & 60.8 & Total & 570 & 100.0 \\
\hline Single & 218 & 38.0 & Form of Employment & & \\
\hline Divorced & 4 & 0.6 & Permanent Staff & 149 & 22.1 \\
\hline Widowed & 4 & 0.6 & Fixed Term Contract & 271 & 55.7 \\
\hline Total & 570 & 100.0 & Article 35 & 39 & 5.7 \\
\hline Academic Title & & & $50 / \mathrm{d}$ & 85 & 12.7 \\
\hline Research Assistant & 201 & 33.6 & Article 33 & 23 & 3.4 \\
\hline University Lecturer & 75 & 14.5 & Other - FDP & 3 & 0.4 \\
\hline Assistant Professor & 107 & 19.4 & Total & 570 & 100.0 \\
\hline Associate Professor & 92 & 16.1 & Work Arrangement & & \\
\hline Professor & 95 & 16.4 & Full Time & 543 & 94.4 \\
\hline Total & 570 & 100.0 & Part Time & 13 & 2.7 \\
\hline $\begin{array}{l}\text { Total Number of Years } \\
\text { in Organisation }\end{array}$ & & & Flexible Time & 14 & 2.9 \\
\hline 1 year or less & 52 & 9.1 & Total & 570 & 100.0 \\
\hline $2-5$ years & 161 & 8.3 & Overtime & & \\
\hline $6-10$ years & 150 & 28.0 & No Overtime & 88 & 16.2 \\
\hline $11-15$ years & 74 & 12.9 & 5 hours or less & 117 & 21.0 \\
\hline $16-20$ years & 48 & 8.3 & 6-10 hours & 162 & 27.8 \\
\hline 21 years or over & 85 & 13.2 & 11-15 hours & 83 & 14.2 \\
\hline Total & 570 & 100.0 & 16 hours or more & 110 & 20.7 \\
\hline & & & Total & 570 & 100.0 \\
\hline
\end{tabular}

\footnotetext{
${ }^{2}$ Responses were coded starting from 1 when entered into the SPSS (e.g. Female $=1$, Male $=2 ; 25$ and under $=1$, $26-30=2,31-35=3,36-40=4$, etc. $)$.
} 


\subsection{Relationship between the Quality of Work Life and Demographics, Working Conditions and the Perception about Organisational Protectiveness}

Table 2 shows the correlation between the quality of work life and working conditions (academic title, salary, total number of years in the organisation, total number of years at the position, form of employment, work arrangement and overtime), the perception about organisational protectiveness and demographics (age, gender and marital status) within the framework of the hypotheses stated.

Table 2 Correlation between the Quality of Work Life and Working Conditions, Perception about Organisational Protectiveness and Demographics

\begin{tabular}{llc}
\hline & \multicolumn{2}{c}{ Quality of Work Life } \\
& \multicolumn{1}{r}{} & $\boldsymbol{p}$ \\
\hline Academic Title & $.388^{* * *}$ & .000 \\
Salary & $.391^{* * *}$ & .000 \\
Duration in Organisation & $.229^{* * *}$ & .000 \\
Duration at Position & $.192^{* * *}$ & .000 \\
Form of Employment & $-.306^{* * *}$ & .000 \\
Arrangement of Work & -.031 & .457 \\
Overtime & .028 & .499 \\
Sex & $.161^{* * *}$ & .000 \\
Age & $.326^{* * *}$ & .000 \\
Marital Status & -.122 & $.003^{* *}$ \\
Perception about & $-.286^{* * *}$ & .000 \\
Organisational & & \\
Protectiveness & & \\
\hline *p<0.05; $* * \mathrm{p}<0.01 ; * * * \mathrm{p}<0.001$ & &
\end{tabular}

Results in Table 2 show that there is no correlation between the quality of work life and the arrangement of work and overtime, yet there is a positive and significant correlation between the quality of work life and academic title $(\mathrm{r}=.388 ; \mathrm{p}<0.001)$, duration of work in the 
organisation ( $r=.229 ; \mathrm{p}<0.001)$, duration of work at the current position $(r=.192 ; \mathrm{p}<0.001)$, and salary $(r=.391 ; \mathrm{p}<0.001)$, and a negative significant correlation between the quality of work life and the form of employment ( $r=-.306 ; \mathrm{p}<0.001)$. The stronger correlation with the quality of work life is with salary and academic title respectively. These findings indicate that hypothesis 6 and 7 are not supported, while hypotheses 1,2, 3, 4 and 5 are supported.

On the other hand, an examination of the relationship between the quality of work life and age, gender and marital status has shown that there is a positive and significant relationship between the quality of work life and gender $(r=.161 ; \mathrm{p}<0.001)$ and age $(r=.326 ; \mathrm{p}<0.001)$, yet there is a negative and significant correlation between the quality of work life and marital status $(r=-.122 ; \mathrm{p}<0.01)$. Among demographics, it is observed that the age variable has a stronger relationship with the quality of work life compared to other demographic features. Therefore, hypothesis $9 \mathrm{a}$ and $9 \mathrm{~b}$ but hypothesis $9 \mathrm{c}$ is not supported.

Table 2 shows a negative and significant correlation between the quality of work life and the participants' perception about the organisational protectiveness $(r=-.286 ; \mathrm{p}<0.001)$. Responses to the question "Do you think the university you are working for treats you in a protective, safeguarding and embracing manner?" [Yes (1) and No (2)] show that the quality of work life is lower for those academicians who think that their organisation is not protective and safeguarding towards them.

An examination of the relationship between the quality of work life and all variables shows that the most significant and positive relationship with the quality of work life of academicians is salary, which is followed by academic title and form of employment. 


\subsection{Results of the Hierarchical Multiple Regression Analysis}

A hierarchical multiple regression analysis was conducted to answer the question "Which of the following does have more impact on the quality of work life: working conditions, perception about organisational protectiveness or demographics? The analysis considered the quality of work life as a dependent variable, and tried to reveal the variable with the most impact on the quality of work life in three stages. Based on the results of the pre-conducted correlation analysis, Stage 1 in Table 3 showed the impact of academic title, the number of years in the organisation, the number of years at the current position, salary and the form of employment on the quality of work life. According to Stage 1, the factors with most impact on the quality of work life of the academicians are, respectively, salary and form of employment. The impact of the salary is in a positive direction while the impact of the form of employment is in a negative direction. Working conditions as a whole explain approximately $18 \%$ of the change of the quality of work life.

Table 3 Hierarchical Multiple Regression Analysis Showing the Impact of Working Conditions, Perception about the Organisational Protectiveness and Demographics on the Quality of Work Life

\begin{tabular}{lcc}
\hline \multicolumn{3}{c}{ Quality of Work Life (Dependent Variable) } \\
\hline Stage 1 & Beta & $\boldsymbol{\beta}$ coefficients \\
\hline Fixed & 71.767 & \\
Academic Title & 1.125 & .111 \\
Duration of Work in the Organisation & -.492 & -.050 \\
Duration of Work at the Current Position & .600 & .047 \\
Salary & 2.632 & $.247^{* *}$ \\
Form of Employment & -1.871 & $-.141^{* *}$ \\
\hline
\end{tabular}

Stage 2

$\begin{array}{lrc}\text { Fixed } & 82.202 & \\ \text { Academic Title } & .660 & .065 \\ \text { Duration of Work in the Organisation } & -.308 & -.031 \\ \text { Duration of Work at the Current Position } & .619 & .048 \\ \text { Salary } & 3.036 & .284^{* * *}\end{array}$




\begin{tabular}{lcc} 
Form of Employment & -1.806 & $-.136^{* *}$ \\
Organisational Protectiveness & -7.181 & $-.289^{* * *}$ \\
\hline Stage 3 & & \\
\hline Fixed & 81.422 & \\
Academic Title & .553 & .055 \\
Duration of Work in the Organisation & -.146 & -.015 \\
Duration of Work at the Current Position & .633 & .049 \\
Salary & 3.017 & $.283^{* * *}$ \\
Form of Employment & -1.835 & $-.138^{* *}$ \\
Organisational Protectiveness & -7.255 & $-.292^{* * *}$ \\
Gender & 2.178 & .071 \\
Age & -.233 & -.030 \\
Marital Status & -1.171 & -.047 \\
\hline
\end{tabular}

Model 1

$\mathrm{R}=.425 \quad \mathrm{R}^{2}=.180 \quad \mathrm{~F}=24.808 \quad \mathrm{p}<0.001$

\section{Model 2}

$\mathrm{R}=.513 \quad \mathrm{R}^{2}=.263 \quad \mathrm{~F}=33.491 \quad \mathrm{p}<0.001$

\section{Model 3}

$\frac{\mathrm{R}=.521 \quad \mathrm{R} 2=.271 \quad \mathrm{~F}=23.144 \quad \mathrm{p}<0.01}{* \mathrm{p}<0.05, \quad * * \mathrm{p}<0.01, * * * \mathrm{p}<0.001}$

Based on the results from Stage 2, which includes working conditions (Stage 1) as well as the perceptions of the academicians about protectiveness of the university they are working for, it is revealed that there is a change in $\mathrm{R} 2(\mathrm{R} 2$ change $=0.83, \mathrm{p}<0.001)$. According to these results, working conditions and the perception about organisational protectiveness, altogether, explain approximately $26 \%$ of total change observed in the quality of work life of the academicians. Where Stage 2 is concerned, it is seen that the most effective variables for the quality of work life of the academicians are, respectively, the perception about organisational protectiveness, salary and the form of employment. Of these variables, salary has a positive impact whereas the form of employment and the organisational protectiveness has a negative impact on the quality of work life. Thus, the quality of work life of permanent staff who thinks that the organisation is protective and safeguarding is higher than of those who work on a 
contract basis and who think that the organisation is not protective and safeguarding towards its employees.

An examination of Stage 3, including demographics in addition to the working conditions and the perception about organisational protectiveness, shows that there is a change in $\mathrm{R} 2$ ( R2 change $=0.08, \mathrm{p}>0.05)$ yet this change is not statistically significant. Based on these results, demographics, working conditions and the perception about organisational protectiveness, altogether, explain approximately $27 \%$ of total change observed in the quality of work life of the academicians. Where Stage 2 is concerned, it is seen that the most effective variables for the quality of work life of the academicians are, respectively, the perception about organisational protectiveness, salary and the form of employment. It is seen that demographics, added in Stage 3 as independent variables, do not have an impact on the quality of work life. As in Stage 2, salary has a positive impact whereas the form of employment and the organisational protectiveness has a negative impact on the quality of work life in Stage 3.

\section{Conclusion and Discussion}

This study has two goals: First of all, to examine whether there is a relationship between the quality of work life and several variables (salary, academic title, total duration of work in the organisation, total duration of work at the position, form of employment, work arrangement, overtime, perception about organisational protectiveness as well as age, gender and marital status), and secondly to reveal which variable has influenced the quality of work life most.

Results from correlation analyses show that there is highly positive significant relationship between salary and QWL. This finding is consistent with the findings in previous studies (Lewis et al. 2001; Toplu 1999; Royuela et al. 2007; Sirgy et al. 2008; Bolhari et al. 
2011). As indicated by Islam and Siengthai (2009), "wage policy affects organizational performance. Wage policy is the core components to measure employees' satisfaction and quality of work life". Findings indicate that there is positive and significant relationship between academic title and QWL. This result is also consistent with the findings in the literature revealing a significant relationship between the quality of work life and career/promotion (Beh 2006; Rose et al. 2006; Winter et al. 2000; Sirgy et al. 2008). The study conducted by Winter et al. (2000) to examine the quality of work life of the academicians in Australia has resulted in a positive relationship between academic titles and the quality of work life of the academicians.

This study is consistent with the previous studies resulted in a positive and significant relationship between the quality of work life and the duration of work in the relevant organisation (Ssesanga and Garrett 2005; Rose et al. 2006; Judge and Bretz 1994; Rose et al. 2006; Bolhari et al. 2011). The longer the duration of work in an organisation and at the current position may also point out to the existence of a kind of job security in that organisation. Organisation of Economic Cooperation and Development (OECD), highlighted that job security, the central aspect of QWL represents strength of the organizations to provide permanent and stable employment regardless of the changes in work environment (Rethinam and Ismail 2008). This study considers the total duration of work at the university within the context of job security that is accepted as one of the most important factors affecting the quality of work life. Several studies have revealed that the existence of job security in an organisation is a crucial factor for improving the quality of work life (Sirgy et al. 2001; Rethinam and Ismail 2008; Winter et al. 2000; Igbaria et al. 1994).

No significant relationship is found between the quality of work life, work arrangement and overtime. This information is in conflict with the studies conducted on the indicators for the quality of work life resulting in that work arrangement is influential on the quality of work 
life (Royuela et al. 2007; Sirgy, et al. 2001; Chisholm 1983) as well as with the studies revealing that such conditions as extra workload and overtime have a negative impact on the quality of work life (Sirgy et al. 2001).

The related literature includes several studies on the relationship between the quality of work life and many variables as well as the impact of these variables on the quality of work life, the most important of which are considered under the 'working conditions' title (income, workload, job security, duration of work, career, work arrangement) and demographics. This study adds a new variable conceptualised with the concept of 'organisational protectiveness' and tries to reveal which variables have the most effect on the quality of work life. The correlation analysis has resulted in a negative and significant relationship between the quality of work life and employees' perception of organisational protectiveness.

As a result of this study, it is found out that there is a positive and meaningful relationship between the quality of work life and age and gender while a negative and significant relationship with gender. This finding is consistent with the literature (Igbaria et al. 1994; Ssesanga and Garrett 2005; Rose et al. 2006; Koonmee and Virakul, 2007; Bolhari et al. 2011).

Hierarchical multiple regression analysis has helped to answer the following question: "Which of the following does have more impact on the quality of work life: working conditions, perception about organisational protectiveness or demographics? The results of the analysis show that the working conditions proved to have a relationship with the quality of work life (salary, academic title, total duration of work in the organisation, total duration of work at the current position, form of employment) is more influential on the quality of work life compared to the other variables. The perception about the organisational protectiveness is less influential 
on the quality of work life than the sum of all working conditions, yet more than demographics. A detailed individual analysis of the impact of all variables (related working conditions, perception about organisational protectiveness and demographics) on the quality of work life shows that the perception about organisational protectiveness has the highest impact alone compared to the form of employment and salary. At Stage 1 the highest impact on the quality of work life is of salary, whereas at State 2 and Stage 3 the perception about organisational protectiveness is the one with the highest impact.

As expressed previously, a negative and significant relationship has been found between the quality of work life and the perception about organisational protectiveness as a result of the correlation analysis. Hierarchical multiple regression analysis has added the perception of organisational protectiveness to the other variables, and examined the impact of all variables on the quality of work life individually, which has led to the perception of organisational protectiveness with the highest impact. This finding may be explained within the social exchange theory established in the framework of non-economical mutuality. The core of this theory is mutuality. Mutuality is the obligation to respond positively to an appropriate behaviour from others (Eisenberger et al. 1997:812). When this rule of mutuality is applied to organisational relationships, we see that employees who believe that they receive the support of the organisation they are working for will feel obliged to give a positive respond to the organisation (Eisenberger et al. 2001). Thus, according to the social exchange theory, any employee who feels that he is treated positively will respond positively to this behaviour. In this study as well, it is seen that the quality of work life of those employees who feel the support and protectiveness of their organisation is higher as a positive reaction to the behaviour of the organisation. Social exchange theory is proved by "the negative and significant relationship between organisational protectiveness and the quality of work life" and "having the highest impact (negative) on the quality of work life". 
Data collected under this study should be interpreted in the light of the state of the participant academicians. In Turkey, as the academic title advances the salaries increase; plus, there are more changes and improvements in working conditions such as occupational rights, social opportunities, job security, etc. Therefore, the positive and significant relationship revealed between the quality of work life and salary and academic title is an expected and meaningful finding. Low wages received by Turkish academicians are stated in several studies (Özdemir et al. 2006; Gümüş 2008; Türk Eğitim-Sen 2009): “Most of the academicians working for private and state universities in Turkey considered the low salary as the most important problem of academicians." Therefore, it is an expected outcome that the quality of work life improves as salary increases.

On the other hand, being one of the variables with most influence on the quality of work life, the form of employment is dealt with within the contest of job security. It is an anticipated finding of the study that the quality of work life varies by the form of employment of the academicians. In the study, the quality of work life of the academicians with permanent position is higher than of the others. An academician with a permanent position has a clear job security compared to other academicians with other forms of employment (e.g. Fixed Term Contract, 50/d, 33/a). In Turkey, academicians with permanent positions at a state university are professors and associate professors. Contracts of the other academicians working for state universities are renewed in every one, two or three years depending on the academic title. For example, contract of a research assistant with a 50/d position is renewed on a yearly basis while one with a 33/a position is renewed in every three years. In addition, 50/d position is considered as a scholarship limited to graduate degree and it is possible that the person in question may be broken off from the position as soon as the duration of education is completed. Nevertheless 
the 33/a position is not defined by a limited period of time based on graduate studies at the completion of which the contract is terminated automatically. Contracts of prelectors, instructors, assistant professors are renewed in every two years, It is possible to terminate the contract of an assistant professor at the end of the contract period. In private (foundation) universities in Turkey, however, academicians are employed on a fixed term contract basis and do not have any job security whatsoever for any academic title. From an organisational point of view, the fact that research assistants, prelectors and assistant professors working for state universities do not have job security and that in private universities no academician has such job security may explain the following findings of this study: "there is a negative significant relationship between the quality of work life and the form of employment" and "the form of employment has a negative impact on the quality of work life".

According to the Spillover theory developed to explain the quality of life, and accordingly the quality of work life, satisfaction in work life influences non-working areas (e.g. family, spare time, health, education, and friendship) and ensures high level satisfaction in these areas (Rice et al. 1980; Sirgy et al. 2001; Chan and Wyatt 2007). In view of the fact that the quality of work life may roll out to affect other aspects of life, it is crucially important to improve the quality of work life of the academicians working for higher education institutions that are training individuals and making scientific research. Within this framework, the main task is of policy makers and implementing units, particularly the management level at the universities, in order to improve the quality of work life for the academicians. Findings of this study may suggest that the policy makers and implementing units, particularly the management level at the universities, develop those factors having an impact on the quality of work life (e.g. salary, form of employment and the perception about organisational protectiveness) for the benefit of academicians (e.g. salary increase, ensuring job security for academicians, safeguarding the academicians at every stake and condition). 
There are several limitations of this study. First of all, the sample of this study is consisted of faculty members working for the faculties of Science, Literature, Education, Engineering and Economics and Administrative Sciences of four different universities in Ankara, Turkey. In order to generalise the results of this study to all academicians working for the state and private universities in Turkey, similar studies should be conducted in different state and private universities in different cities. Secondly, the study should be administered in various sectors and organisations and in different occupational groups to cover a larger sample in order to facilitate handling the findings in a larger context. The study makes a contribution to the QWL literature in understanding the quality of work life and its antecedents in the Ankara area of Turkey. A QWL comparison in different cultures and sectors may also have interesting results. Thirdly, this study puts forward that the state of organisational protectiveness has a major impact on the quality of work life. Is this result peculiar to this sample only or is it a widespread phenomenon in Turkish organisations? It is also possible to suggest international comparative studies to see the impact of the perception of organisational protectiveness on the quality of work life. 


\section{Özet}

Bu çalışma, çalışma yaşam kalitesinin akademik unvan, ücret, örgütteki toplam çalışma yılı, pozisyondaki toplam çalışma yılı, istihdam biçimi, çalışma şekli (full-time, part-time, etc.) ve fazla mesai, örgütün koruyucu olup olmadığına yönelik algı ile yaş, cinsiyet ve medeni durum gibi demografik özellikler ile arasında anlamlı bir ilişki olup olmadığını ve tüm bu değişkenlerin çalışma yaşam kalitesi üzerindeki etkisini incelemektedir.

Çalışmanın örneklemini, Ankara'daki 4 üniversite çalışan 570 akademisyen oluşturmaktadır. Çalışmanın verileri, Sirgy et al. (2001) tarafından geliştirilen ve TasdemirAfsar (2011) tarafından Türkiye kültürüne uyarlama çalışması yapılan Çalışma Yaşam Kalitesi Ölçeği ve 14 sorudan oluşan anket formu aracılığıyla toplanmıştır. Yapılan korelasyon analizinde çalışma yaşam kalitesi ile akademik unvan, örgütteki çalışma süresi, pozisyondaki çalışma süresi, ücret, yaş ve cinsiyet arasında pozitif ve anlamlı bir ilişki; çalışma yaşam kalitesi ile istihdam biçimi, medeni durum ve örgütün koruyucu olup olmadığına yönelik algı arasında negatif ve anlamlı bir ilişki bulunmuştur. Buna karşın çalışma yaşam kalitesi ile çalışma şekli ve fazla mesai arasında anlamlı ilişki bulunmamıştır. Çalışmada yapılan hiyerarşik çoklu regresyon analizi sonucunda, Adım 1'de çalışma yaşam kalitesi üzerindeki en yüksek etkiyi ücret gösterirken Adım 2 ve Adım 3 'te çalışma yaşam kalitesi üzerindeki en fazla etkiyi örgütün koruyucu olup olmadığına yönelik algı göstermektedir. 


\section{REFERENCES}

Arnold, H. J., \& Feldman., D. C. (1986). Organizational Behavior, Newyork: Mc. Graw Hill Book Co.

Baba, V. V. \& Jamal M. (1991). Routinization of job context and job content as related to employees' quality of working life: A study of Canadian nurses. Journal of Organizational Behavior, 12 (5), 379-386.

Beh L.(2006). Predicting Quality of Work Life: The Implications of Career Dimensions, Academy of Taiwan Information Systems Research. Proceedings of the International Conference on Business and Information, 3 (1). (Non-ISI/Non-SCOPUS Cited Publication).

Bhola, S. S. (2006). A Study of Quality of Work Life in Casting and Machine Shop Industry in Kolhapur. Finance India, 20 (1): 202-208.

Bolhari, A., Rezaeean, Ali. Bolhari, Jafar. Bairamzadeh, Sona \& Soltan, Amir Arzi (2011). The Relationship between Quality of Work Life and Demographic Characteristics of Information Technology Staffs. 2011 International Conference on Computer Communication and Management Proc.of CSIT, 5, IACSIT Press, Singapore.

Can, A. (1991). Çalışma Hayatının Kalitesinin Geliştirilmesi. Verimlilik ve Çalışma Hayatının Kalitesinin Geliştirilmesi Sempozyumu, Ankara: MPM Yayınları.

Cobb, C. W. (2000). Measurement Tools and the Quality Of Life, Redefining Progress, Www.rprogress.org_Accessed 24 June 2008. 
Chisholm R. F. (1983). Quality Of Working Life: Critical Issue for the 80s. Public Productivity Review, 7 (1), 10-25.

Chan, K. W. \& Wyatt, T. A. (2007). Quality of Work Life: A Study of Employees in Shanghai, China. Asia Pacific Business Review, 13 (4), 501-517.

Cummings T.G. \& Worley C.G. (1997). Organization Development and Change. South Western, Ohio.

Davis, L. E., \& Cherns, A. B. (1975) The quality of working life: Problems, Prospects, and the State of the Art (Vol. 1). NewYork: The Free Press.

Davis, L.E. (1983). Design of New Organizations. In H. Kolody \& H.V.beinum (Eds). The Quality of Working Life and the 1980s. (pp. 65-86) New York, Praeger Publisher.

Dereli, T. (1991). Verimli bir Çalışma Ortamı Yaratan Faktörler ve Özellikleri. Verimlilik ve Çalışma Hayatının Kalitesinin Geliştirilmesi Sempozyumu, Milli Prodüktivite Merkezi Yayınları, 442, 83-93.

DuBrin, A.J. (1988). Human Relations: a job oriented approach. New Jersey: PrenticeHall.

Eisenberger, R., Huntington, R., Hutchison, S. \& Sowa, D. (1986). Perceived Organizational Support. Journal of Applied Psychology, 71 (3), 500-507.

Eisenberger, R. Cummings, J., Armeli, S. ve Lynch P. D. (1997). Perceived Organizational Support, Discretionary Treatment and Job Satisfaction, Journal of Apllied Psychology, 82 (5), 812-820.

Glasier, E. (1976). State of the Art, Questions about Quality of Work Life, Personnel. 
Greenberg J.B. \& Baron R.A. (1993) Behavior in Organizations, 4th edn. Alley and Bacon, London.

Groot, W. \& Brink, H. M. (2000). Job Satisfaction, wages and allocation of men and women. In E. Diener ve D. Rahtz (Eds.), Advences in Quality of Life Ttheory and Research, (pp.111-128), Klumer Academic Publishers, Social Indicators Research Series, Volume, 4.

Gümüş, A. (2008). EUA-TUSİAD "Yükseköğretim Sektörü” Raporu: Yükseköğretim İşletmeciliği Projesi. Eğitim Bilim Toplum Dergisi, 6, (23), 130-163.

Gürsel, M., Izgar, H., Altınok, V. \& Kesici, Ş. (2003), Endüstri ve Örgüt Psikolojisi İş Doyumu. Konya: Star Ofset Basim.

Hackman, J. R., \& Oldham, G. R. (1980). Work redesign. Reading, MA: Addison-Wesley.

Hannif Z., Burgess, J. \& Connell J. (2008). Call Centres and the Quality of Work Life:

Towards a Research Agenda. Journal of Industrial Relations, 50(2), 271-284.

Igbaria, M., Parasuraman S. \& Badawy M. K. (1994). Work Experiences, Job Involvement, and Quality of Work Life among Information Systems Personnel. MIS Quarterly, $18(2), 175-201$

Islam, M. Z. \& Siengthai S. (2009). Quality of work life and organizational performance: Empirical evidence from Dhaka Export Processing Zone. Paper presented to ILO Conference on Regulating for Decent Work, Geneva during July 8-10, 2009. http://www.ilo.org/legacy/english/protection/travail/pdf/rdwpaper37a.pdf Accessed 13 October 2012. 
Jenkins D. (1981). QWL, Current Trends and Directions. Toronto Ontario Quality of Working Life Centre and Ministry of Labour, Occasional Paper No. 3.

Judge, T. A. \& Bretz, R. D. (1994). Political influence behavior and career success, Journal of Management. 20, 43-65.

Kalleberg, A.L. (2000). Nonstandard Employment Relations: Part-time, Temporary, and Contract Work. Annual Review of Sociology 26:341-365.

Kohl, M. L \& Schooler, C. (1982). Job conditions and personality: A Longitudinal Assessment of Reciprocal Effects. American Journal of Sociology, 87, 1257-1286.

Koonmee, K. \& Virakul, B. (2007). Ethics, Quality of Work life, and Employee job-related outcomes: A survey of HR and Marketing managers in Thai business. Presented at The 2007 ISQOLS Conference (From QOL Concepts to QOL Performance Measures), December 6-9, 2007, San Diego Marriott Mission Valley, San Diego, California. http://www.hrd.nida.ac.th/administrator/rtefile/rte_19.pdf Accessed 14 June 2009.

Kotze, M. (2005). The Nature and Development of the Construct Quality of Work Life. Acta Academia, 37(2), 96-122.

Lawler E. E. III, (1982). Strategies for Improving the Quality of Work Life. American Psychologist, 37, 486-693.

Lau R.S.M. and Bruce, E.M. (1998). A win-win paradigm for quality of work life and business performance. Human Resource Development Quarterly, 9(3): 211-226.

Lau, T., Wong Y.H., Chan, K.F. \& Law, M. (2001). Information Technology and the Work Environment-Does it Change the Way People Interact at Work. Human Systems Management, 20(3), 267-280. 
Lewis, D. Brazil K., Krueger, P., Lohfeld L. \& Tjam, E. (2001). Extrinsic and Intrinsic Determinants of Quality of Work Life. Leadership in Health Services, 14(2), ix-Xv.

Locke, E. A., (1976). The nature and causes of job Satisfaction. In M. D. Dunnette ve L. M. Hough (Eds.), Handbook of Industrial and Organizational Psychology, (pp. 1319 1328). Palo Alto, C.A.: Consulting Psychologists Press.

Martel, J. P. \& Dupuis, G. (2006). Quality Of Work Life: Theoretical and Methodological Problems, And Presentation Of A New Model And Measuring Instrument. Social Indicators Research. 77, 333-368.

Mirvis, P. H. \& Lawler, E. E. (1984). Accounting For the Quality of Work Life. Journal of Occupational Behavior, 5, 197-212.

Nadler, D. A. \& Lawler, E. E. (1983). Quality of work life: Perspectives and directions. Organizational Dynamics, 11(3), 20-30.

Naumann, S. E., Bies, R. J., \& Martin, C. L. (1995). The roles of organizational support and justice during a layoff. Academy of Management Journal, Best Papers Proceedings 1995, 89-93.

Özdevecioğlu, M. (2003). Algılanan Örgütsel Destek İle Örgütsel Bağlılık Arasındaki İlişkilerin Belirlenmesine Yönelik Bir Araştırma. Dokuz Eylül Üniversitesi I.I.B.F.Dergisi, 18 (2,) $113-130$.

Özdemir, Ç. M., Yüksel G., Cemaloğlu N. \& Diğerleri. (2006). Türkiye Üniversiteleri Öğretim Elemanı Araştırması. Ankara: Gazi Üniversitesi Yayınları. 
Rethinam G. S. \& Ismail, M. (2008). Constructs of Quality of Work Life: A Perspective of Information and Technology Professionals. European Journal of Social Sciences. 7(1), 58-70.

Rice, R.W., Janet, P.N. \& Hunt, R.G. (1980). The job- satisfaction/life-satisfaction relationship:A review of empirical research. Basic and Applied Social Psychology, 1, $37-64$.

Rose, R. C., Beh, L. Uli J. \& Idris. K. (2006). Quality Of Work Life: Implications of Career Dimensions. Journal of Social Sciences. 2 (2), 61-67.

Royuela V., Lopez-Tamayo J. \& Surinach, J. (2007). The Institutional vs. the academic definition of the Quality of work life. What is the focus of the European Commission?. Research Institute of Applied Economics. Working papers 2007/13.

Saraji, G. N. \& Dargahi, H. (2006). Study of Quality of Work Life (QWL). Iranian J Publ Health, 35 (4), 8-14.

Shamir, B. \& Salomon, I. (1985). Work at Home and Quality of Working Life. The Academy of Management Review, 10 (3), 455-464

Sirgy, M. J., Efraty, D., Siegel, P. \& Lee, D. J. (2001). A New Measure of Quality of Work Life (QWL) Based on Need Satisfaction and Spillover Theories. Social Indicators Research. 55, 241-302.

Sirgy, M. J., Reilly, N., Wu J. \& Efraty, D. (2008). A Work-Life Identity Model of WellBeing: Towards a Research Agenda Linking Quality-of-Work-Life (QWL) Programs with Quality of Life (QOL). Applied Research in Quality of Life, 3(3), 181202. 
Ssesanga, K. \& Garrett, R. M. (2005). Job Satisfaction of University Academics: Perspectives From Uganda. Higher Education 50, 33-56.

Tasdemir Afsar, Selda. (2011). Effect of Quality of Work Life on Organizational Commitment Level: The Quantitative Research on Academicians in State and Foundation Universities (Unpublished $\mathrm{PhD}$ thesis). Hacettepe University, Ankara, Turkey.

Toplu, D. B., (1999). Çalışma Yaşamının Kalitesinin Geliştirilmesi: Türkiye’deki Kamu Kurum Arşivleri Örneği. Türk Kütüphaneciliği. 13 (3), 223-251.

Türk Eğitim-Sen (2009). Türkiye'de Üniversite Sorunu ve Üniversite Çalışanları Üzerine Bir Araştırma, http://www.turkegitimsen.org.tr/lib_basili/94.pdf Accsessed 12 March 2010

Walton, R.E. (1975). Criteria for Quality of Working Life., In L.E. Davis ve A.B. Cherns (Eds.), The Quality of Working Life Vol.1 (s.91-104). New York: The Free Press.

Winter R., Taylor T. \& Sarros J. (2000). Trouble at Mill: Quality of Academic Worklife Issues within a Comprehensive Australian University. Studies in Higher Education, 25 (3), 279-294.

Wurf J. (1982). Labor's View of Quality of Working Life Programs. Journal of Business Ethics, 1 (2), 131-137.

Yıılmaz Ş. (1990). Türkiye'de Verimlilik Sorunları ve MPM'nin Verimliliğe Katkıları. Verimlilik Dergisi, Verimlilik Özel Sayısı. Ankara: MPM Yayınları. 
Yıldırım, E. (2000). Türkiye'deki Toplam Kalite Yönetimi Uygulamalarının İşçiler Ve Endüstri İlişkileri Üzerindeki Etkileri. Toplum ve Bilim, 86, 260-280.

Yousuf S. M. A. (1995). Quality of Working Life As a Function of Socio-Technical System. New Delhi: Mittal Publications.

Yousuf S. M. A. (1996) Evaluating the quality of work life. Management and Labour Studies. $21(1), 5-15$. 